\title{
EVIDENCE-BASED LAWS AND THE ADMINISTRATIVE CAPACITY TO GENERATE INFORMATION FOR THE LEGISLATIVE PROGESS
}

\author{
Danielle Zaror MiralLEs*
}

\begin{abstract}
Traditionally, the legislative practice has been described from the moment the bills enter the Assemblies or Parliaments until they are promulgated into law, but there is a lot of opacity regarding what the doctrine knowes about the previous moment, that is, the pre-legislative procedures, which finally determine the way in which a problem will be approached legislatively, the content that these texts will develop and who has influenced the strategy deployed. This note seeks to make visible certain practices within the administration that allow understanding which is the starting point of a bill, how the knowledge of the administration members is structured and some of its problems, which are the sources of information for the elaboration of diagnoses, what should be the previous steps for the creation of a regulation and the existence of an institutionality that gives certainty, who influences the drafting of a legal text, what have some Latin American countries done to advance on this issue and how an evidence-based bill should be structured so that its result is close to the optimum expected in terms of legal effectiveness and transparency and accountability to citizens. Finally, this note concludes on the benefits derived from the strengthening of administrative capacity that allow generating, structuring and articulating technical, impartial and transparent information to promote evidence-based laws whose follow-up and evaluation allow assess their ex post effectiveness.
\end{abstract}

KEYwORDS: Law-making process, better regulations, evidence-based laws, regulation, legislation.

* Lawyer, Universidad de Concepción (Chile), Master in Economic Law and PhD in Law, Postdoctoral Researcher, Center for Studies in Computer Law, Faculty of Law, University of Chile. The author has been a consultant for the Inter-American Development Bank (IADB), providing legal assistance in Latin American countries. This note was prepared for III Semanas Doctorales Latinoamericanas organized at the Instituto de Investigaciones Jurídicas, UNAM, in December 2019. I want to thank the valuable comments and suggestions from Marco Nambo, Mónica Sales, Diego Leon Gómez, Ángel Saucedo and Manuel Restrepo. Errors and inaccuracies are all my sole responsibility. Email:dzaror@ug.uchile. 
Resumen: La práctica legislativa se ha descrito tradicionalmente desde el momento en que los proyectos de ley ingresan a las Asambleas o Parlamentos hasta que son promulgados como ley, pero existe mucha opacidad respecto a lo que sabe la doctrina sobre el momento previo, esto es, los procedimientos prelegislativos, que finalmente determinan la forma en que se abordará legislativamente un problema, el contenido que desarrollarán dichos textos y quienes han influido en la estrategia desplegada. Esta nota busca visibilizar ciertas prácticas dentro de la administración que permitan comprender cuál es el punto de partida de un proyecto de ley, cómo se estructura el conocimiento de los integrantes de la administración y algunos de sus problemas, cuáles son las fuentes de información para la elaboración de diagnósticos, cuáles deberían ser los pasos previos para la creación de una regulación y la existencia de una institucionalidad que dé certezas, quiénes influyen en la redacción de un texto legal, qué han hecho algunos países de América Latina para avanzar en este tema y cómo debería estructurarse un proyecto de ley basado en evidencia para que su resultado sea cercano al óptimo esperado en términos de eficacia jurídica, transparencia y rendición de cuentas hacia la ciudadanía. Finalmente, esta nota concluye sobre los beneficios derivados del fortalecimiento de la capacidad administrativa que permitan generar, estructurar y articular información técnica, imparcial y transparente para promover leyes basadas en evidencia cuyo seguimiento y evaluación permitan evaluar su eficacia ex post.

Palabras clave: Formación de la Ley, Mejora Regulatoria, Leyes Basadas en Evidencia, Regulación, Legislación.

\section{Table of Contents}

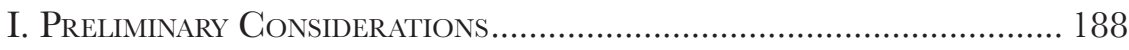

II. How Regulation is Generated Within the State........................ 189

III. Data and Information Available .................................................. 192

1. Principles of Legislation.......................................................... 192

2. Elaboration of a Diagnosis ...................................................... 193

IV. Administrative Procedure for Generating Information To Justify the Regulation ....................................................... 196

V. Expert Participation .................................................................. 198

VI. Statement of Reasons ............................................................... 200

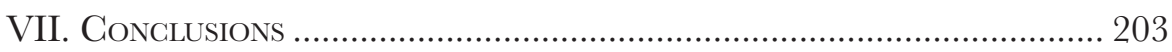

\section{Preliminary Considerations}

One of the biggest challenges in legislation, at a global level, is the need to provide a satisfactory regulatory response to the problems that it is intended to solve. 
This efficiency challenge becomes more evident in Latin America, where the regulation deficits are immense, going from the lack of regulatory frameworks, no longer used or out of date laws, to regulations copied from foreign laws without the adjusting them to the social reality in which they are intended to be applied. ${ }^{1}$

This note seeks to provide a modest insight on several topics. The first relates to the existing capacity within States to generate information likely to be used for political decision-making; the second relates to the existence of administrative procedures or other forms of institutionality within the State where this information can be brought together for legislative purposes; and the third relates to the way in which information and procedures can facilitate the drafting and processing of evidence-based laws.

It is noted that this note does not consider the popular initiative of law as part of its analysis. The note will take elements mainly from the Chilean reality, notwithstanding the review of some procedures or instruments from other Latin American countries.

\section{How Regulation is Generated Within the STATE}

Regulations within democratic states are generated as a rule through lawmaking processes that take place in the Congress or Parliament. ${ }^{2}$ In addition, the Executive Branch has certain administrative powers that allow it to regulate autonomously, without discussion with other branches of government, certain acts that are either not subject to law or have been authorized by it to do so in a more detailed manner (decrees or other forms of subordinate regulations). In the case of Chile, the lawmaking process ${ }^{3}$ is constitutionally based

1 Regulatory deficits could be understood as the result of shortcomings that precede them. Thereon, see Bernardo Kliksberg, ¿Cómo enfrentar los déficits sociales de América Latina? Acerca de Mitos, Ideas Renovadoras y el Papel de la Cultura, 41 (166) Revista Mexicana de Ciencias Políticas y SOCIALES 89 (1996).

2 Mercedes García M., El Procedimiento Legislativo en América Latina, 38 AmÉRICa Latina HoY 17-55 (2004). This work clearly explains the centralization of the legislative initiative in the executive powers and the establishment of the discussion of the laws in the Parliaments.

3 Its concept is divided between what is understood by political science (process) and the philosophy of law (procedure), in this last sphere it is possible to define it as a "legally preordered sequence of the activities of various subjects, in order to achieve a result determined: the formation (or rejection) of the law". Sebastian Soto, National Congress and Legislative Process. Theory and practice 7 (Legal Publishing Chile, 2015). The same author on page 8 , defines it as "the union of a set of stages and formal acts that allow the study, debate, vote, and approval of a bill and in which various authorities, officials and other interested parties take part in order to influence the content and processing of the law, which is the case, it will be finally published". 
in the National Congress and the President of the Republic, both entities in their capacity as colegislators, concur in the lawmaking process.

This process, whose regulation is expressly described in the Political Constitution, is also detailed in the Constitutional Organic Law of the National Congress, and reveals the existence of a flow of bilateral, and indeed bidirectional, exhortations between the President of the Republic, through the respective Ministry, and the National Congress, through the Senate or the Chamber of Deputies. Both parties exchange technical and political arguments on the bill presented, a discussion that gives shape to the new text that will become the future law, which after being approved in both chambers is sent to the President of the Republic who, if he/she also approves it, will arrange for its enactment as a law (Article 72 of the Chilean Constitution).

Among the characteristics of this process, we cannot fail to mention that it is reserved by constitutional means, most of them and the most important matters of law, to the President of the Republic. In other words, the initiative of this law-making process is placed in the hands of the Executive Branch through the sending of the respective Message, which is nothing but a clear example of the president-centered system of government that prevails in Chile.

In Chile, the members of parliament divided in two chambers, both deputies and senators, also have legislative initiative, which is materialized through the so-called parliamentary Motion. The importance of the subjects they can address is less relevant than the type of initiative the President of the Republic can have.

This context explains the model that allows the creation of regulations in two ways: in a heteronomous manner within the Assemblies or Parliaments and in an autonomous manner either by constitutional or legal authorization, where the result of both actions will imply the coexistence of rules of greater and lesser hierarchy.

José Meehan ${ }^{4}$ has classified the above procedure (of top hierarchy) as that part relating to external legislative technique, namely, that relating to the preparation, issuance and publication of legislative acts. The internal legislative technique refers to the analysis of the form and content of the project. It is this last technique that is of interest in this work.

Indeed, the description of what the administrative and epistemic practices of the administration are when creating regulatory projects is scarcely discussed. As we have already mentioned, Latin America has a well-known lack of regulation in various areas, in addition to regulatory frameworks that are too old (frankly obsolete) or without the necessary hierarchy to be recognized by the compelled subjects.

As a general rule, the first drive that produces regulation in the countries is given by government plans or programs, which are true roadmaps where the

4 José Meehan. Teoría y Técnicas Legislativas 73 (Ediciones Depalma, 1976) 
political project of each coalition is expressed before the election and, once they are elected, they allow them to execute a legislative agenda based on the proposals that the citizens favored with their vote.

But there are also other origins for this legislative starting point; a common practice in Latin America are the National Development Plans, which are management tools that are submitted by the executive to the Parliament, which once approved provides the limits or priority areas within which the respective country must legislate during the period for which it was approved. ${ }^{5}$

With the thematic framework defined, the next question is to know the state of the art in the respective subject. Knowing this presupposes a certain professional competence of the bureaucracy responsible for drafting the regulations, i.e. knowing professionally the issue to be addressed, the sources of information to be employed and the arguments to be developed to persuade Parliament.

It is therefore a transformative moment, in such terms that the political will, coupled with the information of reality must be converted into a documentary act that reasonably combines both drives.

In the course of this process, and following good practices for public transparency, this type of action should be subject to citizen participation procedures, where the subjects who are to be the recipients of the laws can provide relevant knowledge or intelligence. ${ }^{6}$ If the complexity of the subject matter so warrants it, expert committees could be convened to hear what academia or industry, as the case may be, can contribute in this regard and thus contribute to organizational learning when it is exceeded by the challenges of the legislation.

This is often joined by the participation of an international organization that serves as a promoter of an institutional modernization initiative, by providing either technical assistance or financial resources for the implementation of the new regulations. We will discuss the particularities of their participation and promotion of certain initiatives below.

In the case of subordinate regulations -such as decrees or regulations- the practices of the administration are generally opaque. Often in the face of pressing deadlines, daily urgencies, and the fact that no discussion will be held outside the administration, these regulations will appear approved and published without the slightest public deliberation that could have existed among the technicians and bureaucrats responsible for their creation.

${ }^{5}$ In Latin America, Bolivia, Costa Rica, Colombia, Ecuador and Panama have national development plans. As the objective is strongly focused on poverty, health, education, nutrition, housing, work and gender, it is possible that in many cases it exists under another name, as in the case of Uruguay, which is called the Equity Plan.

6 Beth Simon, Ciudadanos más inteligentes, Estado más inteligente. Las tecnologías DEL CONOCIMIENTO Y EL FUTURO DE GOBERNAR 286 (CIDE, 2017). 


\section{Data AND Information AvaILable}

As noted in previous paragraphs, it is within the administration where, as a general rule ${ }^{7}$, the first letter of any project that should become a regulation is written. To begin this process, it is necessary to have a guiding principle to govern the activity and, of course, the inputs of diagnosis or scenario that will be the subject of regulation.

\section{Principles of Legislation}

In his fascinating work "The Morality of Law", Lon Fuller tells the story of a king named Rex, where he formulates the eight ways in which one can fail in law. Through a simple, yet profound story, he is able to illustrate how a regulator can fail in his task. The calamities he describes include those cases in which laws are no longer created; there is not due publicity for the norms, there is an abuse of retroactive legislation, not making comprehensive laws, but making contradictory laws, that are outside the scope of those affected, causing instability of the legal bodies (through successive changes) and through the lack of congruence between the rules according to which they were promulgated and their actual administration. ${ }^{8}$

This reflection has allowed scholars to offer a series of proposals regarding the formulation or existence of certain principles that should guide legislative activity. We can understand the principles of the formation of the law as "those fundamental criteria for the generation of the law and indispensable for the correct development of the legislative function, applicable preferably to the co-legislating organs in the elaboration of a legal initiative, in its original ideas, in its perfection and in its different constitutional procedures, until the completion of the bill". 9

For example, Jeremy Waldron has pointed out that the principles of legislation could be classified into three types, including substantive principles (common good and general utility), formal principles, and procedural principles. In his work, he focuses on the latter, pointing out that they can be broken down into seven principles that address important aspects of legitimacy. They are particularly important when a debate must be moderated where there are profound differences around substantive principles. This list, however, leaves out the pre-legislative process, since the principles proposed are aimed at regulating a debate in the parliamentary stage and are basi-

7 I mention it as a general rule because in most Latin American countries, parliamentarians have well-circumscribed areas of legal initiative, most of the time on matters that do not require or do not have a national budget impact.

8 Lon Fuller, La Moral del Derecho 43-49 (Editorial Trillas, 1964).

9 Pablo Urquízar \& Cristobal Aguilera C., La Formación de la Ley 29 (Editorial Metropolitana, 2019). 
cally oriented towards ensuring that the debate takes place in a transparent, respectful, and fair environment. ${ }^{10}$

Notwithstanding the above, it is possible to find formulations that are capable of admitting a set of legislative principles or legislation formulated in such broad terms that they would be inclusive for the administrative stage of formation of regulations. Among the variety offered by the doctrine, mention can be made, for example, of the principles of probity, constitutional supremacy, integrity (unity of matter or congruence), precision or certainty, coherence, reasonability, relevance, timeliness, among others. ${ }^{11}$

\section{Elaboration of a Diagnosis}

For the elaboration of an accurate diagnosis, data sources are needed to produce information schemes that make reasonable and understandable for legislators and the rest of the civil society the state of things and the expected objectives after the regulation.

The diagnosis must be clear about the problem or difficulty that the regulation is intended to solve. Its work should not be limited to the normative aspects that the new regulation will modify, but to the whole spectrum of what is related to the matter.

To a greater or lesser extent, the States have the following sources of data that make it possible to prepare information on the problem intended to be solved:

A) Official statistics. All Latin American countries have National Statistics Offices (NSOs). These organizations are in charge of carrying out surveys and censuses (the latter providing the sample framework for the rest of the statistics), which for all legal purposes will be the official information of the State.

It is quite common for statistical systems in Latin America to be decentralized, which means that in addition to the NSOs, the public services themselves generate their own statistics.

In most Latin American countries, with the exception of Mexico and Brazil, practices in this area are at a basic statistical threshold, that is, generating the simplest data. This can be explained by a historical lack of resources that has affected this part of the

10 Jeremy Waldron, Principles of Legislation, in The Least Examined Branch. The Role of Legislatures in the Constitutional State 17, 18 (Bauman, R. y Kahana, T. ed., Cambrigde University Press, 2006).

11 These principles can be reviewed in Israel Campero, Manual de Técnica Legislativa 119 and following (Rotembol Graphic Impressions, 2011); José Minor \& José Roldán, Manual de Técnica Legislativa 73 (H. Cámara de Diputados, Porrua, 2006); Meehan, supra note 4 and UrQuízar y Aguilera, supra note 9, at 30. 
administration, which for inexplicable reasons always lags behind modernization plans. Consequently, the lack of information has resulted in the regulations making little use of this data because they simply do not exist.

The statistical capacity ${ }^{12}$ of States is undoubtedly a relevant starting point for any task involving the generation of information for evidence-based decision-making. Nowadays, studies have begun to be carried out that make the use of statistics in the design of public policies visible at an early stage. ${ }^{13}$

The fact that this information is official means that any regulation originating from the administration, regardless of its hierarchy, must reasonably justify these data that have been collected and processed independently and impartially from the political authorities. In other words, it is official because they are reliably reporting facts of reality.

B) Open data. According to the International Open Data Charter, these are those digital data that are made available with the necessary technical and legal characteristics so that they can be used, reused and redistributed freely by anyone, at any time and in any place. ${ }^{14}$

The State is essentially a generator of open data, and in this sense, Latin America has been a leading student since it has a high number of adoptions of the principles proposed in the Charter. ${ }^{15}$

The availability, in terms of accessibility, cost-free and interoperability, has begun to generate a supply of data that has had an affirmative response by those who seek information, which has meant that they have begun to be part of government practices through the creation of an open data infrastructure, have responded to citizen concerns for greater access to public information, have facilitated the generation of datasets leading to the resolution of specific public policy problems, and have made it possible to create innovative solutions with social impact.

C) Governance with directives. As can be seen from the previous paragraphs, it is quite frequent that within the State there are mechanisms that collect and share data (statistics) or make available (open

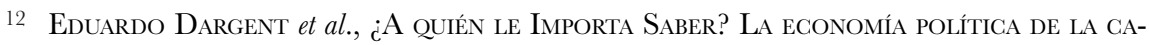
pacidad estadística en América Latina 17 (Banco Interamericano de Desarrollo, 2018). Statistical capacity is defined as the existence of a permanent structure or system that has the necessary resources to consistently generate relevant and quality statistical data, to disseminate them adequately and in a timely manner.

13 Mariko Rusell \& Jorge Muñoz-Ayala, Un estudio exploratorio para Medir el uso DE LAS eStadísticas EN EL Diseño DE POlítica Pública 4 (Banco Interamericano de Desarrollo, 2015).

14 Open DATA CHART (Oct. 17, 2019,) available at https://opendatacharter.net/principles-es/.

15 Arturo Muente-Kunigami, \& Florencia Serale, los Datos Abiertos en América LaTINA y El Caribe 46 (Banco Interamericano de Desarrollo, 2018). 
data) sets of information. What is not frequent are the mechanisms or guidelines that organize and coordinate the way these data will be used later. In fact, it is common for data to be disclosed or available but not to be formally reviewed or invoked when generating information for regulation.

To avoid this disconnection, practices of regulatory improvement or coherence have been promoted within States, that is practices that aim to support governments in improving the quality of their regulation by ensuring that it meets their social objectives. ${ }^{16}$

These practices are mainly promoted by the Organization for Economic Cooperation and Development ${ }^{17}$ and their aim is to organize the available data and translate it into coherent information, in order to provide an account of the state of affairs that will make it possible to demonstrate and convince, which is the starting point for regulatory reform, as well as the objectives that the new regulation seeks to achieve. In general, the corollary of these initiatives is to have evidence-based regulations. Particularly, the vast majority of them seek to simplify procedures or reduce those that are unnecessary.

These practices are materialized through documents that reflect what has been called Regulatory Impact Assessment. In order to materialize this effort, it is also essential to have an institutional framework that allows coordinating the regulatory flow within the State and monitoring the use of information in each of the ex-ante evaluations, the impact and the objectives pursued with the new regulation.

The Latin American countries that have incorporated these guidelines have faced some challenges that are mostly related to the institutionality needed to carry out this task, which, as a rule, is created but lacks enforcement powers. On the other hand, there are challenges associated with the lack of systematic stakeholder participation, mainly due to a lack of knowledge of the mechanism that promotes regulatory improvement. ${ }^{18}$

16 A better regulation process is one aimed at causing changes in a specific legal system, in particular through the improvement, adaptation or updating of current legal instruments or through proposals called to cover legal or regulatory gaps in the respective matter. It is a comprehensive process that goes beyond the mere deregulation or simplification of procedures in a sector. Danielle Zaror, The REgUlatory IMPROVEMENT PROCESS FOR SMALLER COMPANIES IN Chile 69 (Postgraduate tesis, University of Chile, 2009).

17 Recomendación sobre Política y Gobernanza Regulatoria, OCDE (2012) (oct. 17, 2019) available at https://wwweocd.org/regreform/recomendacion-del-consejo-sobre-politica-y-gobernanza-regulatoria-9789264209046-es.htm.

18 Tobías Querbach \& Christiane Arndt, Politica regulatoria en América Latina: Un anÁlisis de la situación actual 11-14 (Documentos de Trabajo de Política Regulatoria de la OCDE, 2017). 


\section{Administrative Procedure for Generating Information TO Justify THE REgULATION}

As noted above, modern states have more or less strongly developed mechanisms for collecting, disseminating and making data available. However, the next phase, which relates to the generation of coherent information to justify regulatory decisions, is an aspect that is still immature.

When looking for information about the existence of administrative procedures related to the lawmaking or regulation process, the truth is that the outlook is rather meager in examples. As Mercedes García said, what is unquestionably regulated is the constitutional lawmaking process, but the previous stage is still an aspect that the States owe in terms of transparency and accountability of the administration.

That said, the pre-legislative procedure, which is the one that interests us, has taken strength in some countries and has begun to become visible through a series of administrative practices, but not necessarily entitled in a legal body (hence its fragility), that allow "ordering ideas" and setting expectations within the administration. Here are some examples:

1) Mexico. In the year 2000, it formalized an institution called the Regulatory Improvement Commission (COFEMER), which is responsible for carrying out the procedure for regulatory improvement in this territory. Mexico is the most significant case in this matter since it is the only country that has established by federal law of administrative procedure a practice of this nature, which is materialized through the so-called Statement of Regulatory Impact (MIR). This norm also created a Regulatory Improvement Council for public and private integration that achieved the objective of systematizing the participation of public entities and the private sector. Among the main attributions of COFEMER, we can mention:

A) It revises the national regulatory framework, diagnoses its application, $\mathrm{m}$ and elaborates legislative and administrative proposals, as well as programs to improve regulation in specific activities or economic sectors.

B) It analyzes and dictates the regulations intended to be issued by the Federal Government's agencies and decentralized bodies, in order to guarantee that their impact, in terms of social benefits, is greater than their costs.

C) It administers the Federal Registry of Procedures and Services, which is an inventory of the procedures of the Federal Public Administration. The agencies and decentralized organizations may not apply additional procedures to those registered in this registry or apply them differently from what is established in it. 
D) It provides technical advice on regulatory improvement for federal entities and municipalities in the country, which is to promote local regulatory improvement laws, adjustments to local regulations and public announcements, systems of rapid opening of companies and state and municipal councils of regulatory improvement.

2) Costa Rica. Law No. 8220 of 2002 established the Protection of Citizens from Excess of Requirements and Administrative Procedures. A Regulatory Improvement Management was created with the mission of leading public and private efforts to achieve an efficient regulatory framework, without unnecessary paperwork or requirements, and without overlapping competition between institutions, which provides legal certainty to the administered, generating a favorable investment climate for companies and a State that provides satisfactory services to citizens and guarantees the protection of their interests. It is also an outstanding example of institutionality with the objective of achieving "efficient" regulation for a better State for its citizens.

3) Chile. It has been trying to develop an ex-ante regulatory impact assessment policy at least since 2009, when it joined the OECD. These efforts, however, have not succeeded in having a transversal concretion in the State.

In 2010, Law No. 20416 was passed, establishing special rules for smaller companies. Article 5 of this law declares a Procedure for the Issuance of General Regulations and Rules, stating that:

All ministries or agencies that issue or modify general legal norms that affect smaller companies, with the exception of municipal ordinances and the rulings that may be issued by State Administration agencies, must keep at permanent availability of the public the necessary preparatory background they deem relevant for their formulation, in their websites, under the terms set forth in Article 7 of Law No. 20285. The precedents must contain a simple estimate of the social and economic impact that the new regulation will generate in the smaller companies and may be prepared by the Administration itself [...] However, the failure to comply with the obligations referred to in the preceding paragraphs will not affect in any case the validity of the act.

As can be seen from the wording of this norm, there is an obligation to think about the impacts that the new regulation will cause, but if this is not done, there is no ensuing consequence. The regulatory impact form, despite being considered an active transparency obligation, has been so far scarcely used.

The lack of institutionality and the poor use of the impact evaluation document led to the creation in 2015, by means of a decree, 
of the National Productivity Commission (GNP), which is an advisory, independent and autonomous institution with a mandate to increase productivity in order to improve the life and well-being of the people. The GNP advises the Government of Chile on matters geared towards increasing productivity, proposing public policies, technically supported, that consider the opinion of civil society, with a focus on improving the welfare of citizens.

As can be seen, the institutional framework is fragile and the focus is quite partial, since the only focus on which evidence is sought is that related to productivity.

\section{Expert Participation}

It is quite frequent that during the pre-legislative process, the professionals of the respective public departments take on the task of drafting the bill that will be presented to Parliament. ${ }^{19}$ However, since the process of creating regulations does not necessarily imply formal knowledge, this responds to an urgent social problem that makes it necessary to combine a greater number of aspects, such as the achievement of a politically complex proposal that needs to have a high degree of agreement; administrations usually resort to the talent of professional experts who, within the agency or outside it, will allow for a technical deliberation of the matters submitted to their knowledge. So, for example, we can see Technical Teams, External Commissions, In-house Experts and International Consulting, among others.

1) Technical Teams. When the complexity of the subject requires it, it is very frequent that technical teams from one or more public departments are assembled, made up of professionals from one or more disciplines. The result of these teams should be a unique proposal that harmoniously resolves the challenges of each of the sectors represented in the team.

2) External commissions. They can be of a temporary nature or they can be held in session after being summoned by the authority that implements them. As a general rule, they have an ad honorem nature and usually combine a good balance of political forces, and gender, this last criterion being a condition sine qua non these days.

Regardless of the fact that these types of commissions have political balances in mind, they are integrated by people of well-known

19 Exceptionally, an external entity may be entrusted with the total or partial review of the factual and legal bases for the administration to take a decision. These types of reports are frequent when what is reviewed has to do with the creation of infrastructure and they are duly remunerated through the platforms that regulate public purchases. 
prestige, professional or academic, or renown by their leadership in the subjects on which they will contribute.

These commissions can be classified as:

A) Advisory Council. These are integrated by those who collaborate with the authorities to make certain decisions by providing arguments, experiences and research to support a particular decision. They meet for a determined period of time, which once extinguished should result in the delivery of a proposal. In Chile, for example, the "Advisory Council for the Modernization of the State" is an entity that made recommendations directly to the President of the Republic regarding regulatory urgencies for the state modernization process.

G) Resolution councils. They are those which are established by law and have the competence to approve or reject any measure or proposal. In the case of these Councils, it is difficult to make progress on regulatory changes without their express consent. As a general rule, this type of organ makes no other effort in this process than to give its approval or rejection, which in many cases can be critical. They hold sessions if there are issues that warrant their establishment.

D) Consulting Councils. These are instances of consultation on a decision to be made where the response to the consultation received is not necessarily binding on the body that made the decision. These councils can be technical or simply call on interested civil society and their outcome is translated into proposals that can be as many as there are members.

3) In-house Experts. On other occasions, the matters to be resolved for the regulatory proposal are of such complexity that this type of highly trained advisors must be sought in the private sector and internalized to work exclusively on the drafting of the regulatory proposal, which once completed may mean the end of the labor relationship with said expert.

4) International Consulting. In Latin American countries, it is quite common to find experiences where various public agencies are advised, and in many cases financed in part of their operation, by international entities. It is interesting to look at this type of support in the process of creating regulations, since these entities often promote ideas about what would be right in certain areas. Thus, good international practices are well known to all good regulators, and they form part of almost all the explanatory statements of draft laws. The promise behind many of these Best Practices is that they pave a path to development, a goal so elusive and so pursued in our continent. 
This relationship between law and development has been studied extensively in the U.S. academia, but very little in Latin American academia. It is interesting to see how the vision that considers law as an instrument to introduce transformations in social and economic matters is still very much alive.

These organizations provide experts who are convinced that there is a causal link between legal change and consequent development, that significant reforms will produce the change, and that if the part in need of regulation is well identified, the adjustment will bring about development.

This group of advisors also provides practical and comparative experience through what they have been able to see work out and fail in each of the countries where they have given their advice.

Most of these organizations frequently promote legal transplants, which, as we know, will have to overcome multiple obstacles associated with the social, economic, political or cultural complexities that a given country has.

This type of adjustment, based on successful cases of foreign law, brings many difficulties, among the most frequent being the lack of adjustment with legal systems (when they are different) and the lack of integration with institutional procedures.

Emulating objectives and motivations seem to be part of the limit of what is acceptable, transplanting in a literal way seems to be a path to failure.

There are no studies that have evaluated or measured the role of regulators in the state of progress after the implementation of legal changes (or institutional developments). Consequently, some authors are skeptical of the promises of development through legal changes. ${ }^{20}$

However, this type of advice or technical assistance often provides true navigation charts at the time of writing a regulatory proposal. These advisors do not write the articles, but it is possible to easily identify the "fingerprint" of their participation in the prelegislative process.

\section{Statement of Reasons}

One aspect that should be part of the structure of any bill is the statement of reasons that precedes the text of the articles containing the rules that make up the bill.

In descriptive terms, it is a section that provides an explanation of the historical course of a given situation or institution. In this part we should find

20 Kevin Davis \& Michael Trevilcock, Relationship Between Law and Development. Optimist versus Skeptics, 56 (4) The American Journal of Comparative LaW 895 (2008). 
the origin (material circumstances) that gives the regulatory impulse, which could be based on a scenario that has undergone a crisis, or on the contrary, it could be the result of a long political period that has reflected on it. In many cases, particularly in Latin America, the initiative is reactive to incidents that have caused a great social impact, or it is about issues for which there is little evidence or information, but there is a regulatory tendency that moves the State to legislate (fundamentally when interest groups are capable of rallying public interest).

This part is often seconded by experiences in comparative law that offer different solutions that have been proposed to resolve the issue giving rise to the initiative.

Thereon, the statement of reasons focuses its work on explaining the problem that gives rise to the project, the poor regulation or lack thereof, as the case may be. This part of the exposition can be defined as the diagnosis and in order to provide a clear picture, it is essential that the pre-legislative work is rigorous and adequate.

Next step is to conceptually detail the measures that the bill intends to introduce in the regulation, which would ultimately solve the problems that have been detected in the diagnosis. In this part it is also expected that the legislator will be sufficiently clear and transparent in terms of the main and accessory consequences linked to the implementation of the new regulation. ${ }^{21}$

Finally, it is possible to find the text of the articles that must be consistent with what is indicated in the declarative part of the project. All this information should be sufficient for legislators, the media and civil society to determine whether it is a major or minor legislative change and what has been the rationale (ratio legis) behind the proposal. ${ }^{22}$

All this part is essential for the subsequent evaluation of the expected effects once the law is enforced.

From a constitutional perspective, it should be noted that not all Latin American countries are obliged to present this scheme. The article by Mercedes García, already quoted in this work, gives a good account of the fact that countries such as Argentina, Brazil, Ecuador, and Paraguay are not obliged to accompany the presentation of a bill with this section.

But in countries where this obligation does exist, it should not be neglected, as it is considered essential to account for the significant reasons that trigger a quality legislative procedure.

21 Constanza Inhen, La argumentación por consecuencia en el debate legislativo chileno: preguntas críticas para evaluar su suficiencia, 37 Revista de Lingứística, Filología y Traducción 222 (2016). The Chilean argumentative scheme has been studied and the doctrinal hypotheses suggest that in most cases the new proposal would be (its goodness or benefit) the necessary consequence of the act of regulating in that sense.

22 Osvaldo Oelckers et al., La Evaluación de las Leyes 15 (Ediciones Universitarias de Valparaíso, 2002). 
Among the reasons given for creating an explanatory section is the objective of incorporating core or essential ideas that are necessary to give order and coherence to the legislative debate that will take place within Parliament. In fact, these structural ideas provide a special regulatory framework within which the flow of arguments must move and possible modifications that the legislative initiative may receive. In this sense, the title of the bill is an important part of what should be understood as the core or fundamental ideas, since it is indicative and unequivocally related to the subject matter to be regulated.

The relevance of this point is such, that, for example in the Chilean case, the Constitution provides in its Article 69 that "Every project may be subject to additions or corrections in the corresponding procedures, both in the Chamber of Deputies and in the Senate; but in no case will those that are not directly related to the core or fundamental ideas of the project be admitted".

It has also been estimated that stating these ideas in the explanatory part would fulfill other roles in favor of society and democracy, among them, meaning respect for minorities, generating regulatory certainty, and limiting influence peddling among parliamentarians. ${ }^{23}$

Another aspect in which the explanatory part is constitutionally relevant is related to the transparency to inform what other rules of the current legal system would be affected or modified by the new regulation. This makes the statement of reasons an indispensable part of the subsequent interpretation of the law; therefore, its consultation in case of doubt will make possible a more systemic and harmonious interpretation of the legal system as a whole. ${ }^{24}$

All the above undoubtedly serves, for better intelligence and appreciation of the laws, to prevent the verum sensus that motivated the legislator to act in this way.

A final aspect of the statement of reasons, which is equally indispensable and directly linked to the Constitution, is the transparent declaration of the rationality of spending, that is, how much the economic impact of the new regulation will be on the national budget.

Most of the draft laws "detail the objectives and results sought [...] but they are usually generic statements that seek to inspire a narrative, rather than allowing in a posteriori evaluation of public policies". ${ }^{25}$ In view of the above, it is especially relevant whether the initiative creates a new institutional framework or oversight functions, or whether it should deploy actions with national coverage. It should be noted that this part is different from the evaluation of the economic impact on the regulated, which has already been explained in other paragraphs of this article and which is equally necessary.

23 Sebastián Soto, Congreso Nacional y Proceso Legislativo. Teoría y Práctica 309312 (Thomson Reuters, 2015).

24 In a partially contrary sense, MinOR \& RoLdán, supra note 11, at 18.

25 Urquízar \& Aguilera M., supra note 9, at 92. 


\section{Gonclusions}

This note has offered a reflection on the scenarios faced by a regulator within the administration when a bill must be drafted.

From the reading of the respective sections, it is possible to notice that all States, to a lesser or greater extent, have information generation capacities that let us illustrate a better quality pre-legislative procedure. In fact, to the extent that such information is used, formalized, and requested more frequently for the purposes of creating regulations, it is likely that the areas of knowledge of the respective society will expand and thus the preparation of the regulation as a whole will benefit.

The establishment of a clear diagnosis, which accounts not only for the regulatory scenario but also for the cultural, social and political aspects of a given issue, will undoubtedly be the best starting point for any subsequent legislative discussion.

The determination of the objectives pursued, and the expected results are, on the other hand, the best starting point of evaluation that even in the short term can allow the ex post evaluation or review of a regulation.

A prominent and in full swing aspect involves the implementation, in a more or less formal manner, of administrative procedures or other forms of institutions that allow for the organization of work within the State, especially when the subject matter to be regulated has an impact in more than one way.

As a general rule, there is a perception from the private sector that the generation of regulation obeys an orderly process within the framework of the authority that provides it, but this could not be farther from the truth. Real legal and political battles are fought within the State, especially when the technical teams belong to different sectors. The struggle to make reasons prevail ends up moving to the field of influence where it is frequent that a common authority is the one that must end up deciding in favor of some arguments over others. If the debate is organized, the decision will end up being fairer because there will be no way to circumvent the information that has been raised for these purposes.

Avoiding disputes that wear down the administration is one of the benefits of having a formalized ex ante regulatory evaluation procedure. These procedures add transparency in that they open up a space for other interested parties, both from civil society and from academia, to give their opinion and information on the subject, providing mechanisms for access to information once they are concluded, since they offer citizens effective access to the real reasons behind a regulation.

At this point, we must bear in mind that the participation of industry in these processes must not be neglected, as it often generates information through its trade organizations that the State does not collect or produce precisely because of its weak capacities. 
Among other benefits, we can also mention the creation of certainty regarding the problems to be corrected and the moderation of expectations regarding the expected results. These practices as a whole constitute a great mechanism for accountability in this level, which is transcendental, and in which in many countries it is completely invisible.

These mechanisms also generate large spaces of confluence within the State. Once the procedure is known, those responsible will ensure that the best available information is delivered, generating benefits not only for a given process but for all those who will follow in succession as soon as a regulatory capacity is installed. This in turn generates a virtuous flow, contributing to the creation of a great professional capacity within the State, which in turn allows us to trust precisely that the best experts in a given regulation are also in charge of its modification or transformation.

Finally, generating bills based on evidence allows an honest intervention by the authorities in front of the representative power that is exercised in the Assemblies or Parliaments. In this sense, proposing laws that have resulted from the analysis of data and impartial and reliable information allows for better persuasion of those who, through voting, build the regulatory framework of the Nation.

It is a guarantee for the citizenship that it will rely on the existence of professional and previously established processes for the formulation of regulations, thus removing the ghost of corruption and power dealing for the elaboration of "tailor-made" regulations.

Creating this type of instrument and building a robust institutional framework that allows these practices to mature within the administration ensure a State committed to governing with respect to each of its citizens. 